Arq. Bras. Med. Vet. Zootec., v.71, n.2, p.509-520, 2019

\title{
Direct inhibitory effect of caffeine on viability, synthesis activity and gene expression in cultures of chondrocytes extracted from the articular cartilage of rats
}

[Efeito inibidor direto da cafeína sobre a viabilidade, atividade de síntese e expressão gênica em culturas de condrócitos da cartilagem articular de ratos]

\author{
A.M.S. Reis, K.P. Oliveira, I.H.F. Paula, A.P. Silva, J.F. Tarragô, \\ N.M. Ocarino, R. Serakides*
}

Universidade Federal de Minas Gerais - Belo Horizonte, MG

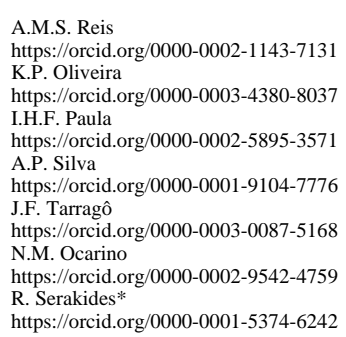

https://orcid h.H.F. Paula A.P. Silva https://orcid.org/0000-0001-9104-7776 J.F. Tarragô N.M. Ocid.org/0000-0003-0087-5168 https://orcid.org/0000-0002-9542-4759 https://orcid.org/0000-0001-5374-624

\begin{abstract}
The aim of this study was to evaluate the effect of concentrations of caffeine on the viability, synthesis activity and gene expression in cultures of chondrocytes. Extracted articular cartilage from the femurs and tibias of 15 Wistar rats at three days old to isolate chondrocytes. Chondrocytes were cultured in chondrogenic medium (control) or supplemented with caffeine $(0.5,1.0,2.0 \mathrm{mM})$. Cell viability, alkaline phosphatase activity and collagen synthesis were assessed using colorimetric assays at 7, 14, 21 days. The chondrocyte cultures of all groups grown under coverslips were stained with hematoxylin-eosin to determine the percentage of cells/field and with PAS, safranin O, alcian blue to determine the percentage of matrix chondrogenic/field at 21 days. The expressions of gene transcripts for aggrecan, collagen-II, Sox-9, Runx-2 and alkaline phosphatase were also evaluated by RT-PCR at 21 days. The means were compared using Student-Newman-Keuls. Caffeine significantly reduced the conversion of MTT to formazan, percentage of cells/field, collagen synthesis, alkaline phosphatase activity, synthesis of PAS+, safranin $\mathrm{O}+$ and alcian blue+ chondrogenic matrix, and the expression of aggrecan, Sox -9 and II collagen. It is concluded that caffeine at concentrations of $0.5,1.0,2.0 \mathrm{mM}$ has a direct inhibitory effect on chondrogenesis in cultures of chondrocytes from rats.
\end{abstract}

Keywords: rats, caffeine, chondrocytes, chondrogenesis

\section{RESUMO}

O objetivo deste estudo foi avaliar o efeito direto de concentrações de cafeína sobre a viabilidade, atividade de síntese e expressão gênica em culturas de condrócitos de ratos. As cartilagens dos fêmures e tíbias de 15 ratos Wistar com três dias foram extraídas para isolamento de condrócitos. Os condrócitos foram cultivados em meio condrogênico (controle) ou em meio acrescido de diferentes concentrações de cafeína (0,5, 1,0, 2,0mM). Foram avaliadas a viabilidade celular, a atividade da fosfatase alcalina e a síntese de colágeno por ensaios colorimétricos aos sete, 14 e 21 dias. Condrócitos cultivados sob lamínulas foram corados pela hematoxilina e eosina, para se determinar a porcentagem de células/campo, e pelo PAS, safranina $O$, alcian Blue, para se determinar a porcentagem de matriz condrogênica/campo aos 21 dias. Foi avaliada a expressão de transcriptos gênicos para Sox-9, Runx-2, agrecano, colágeno-II e fosfatase alcalina por qRT-PCR, aos 21 dias. As médias foram comparadas pelo Student-Newman-Keuls. A cafeína reduziu significativamente o MTT em cristais de formazan, a porcentagem de células/campo, a síntese de colágeno, a atividade da fosfatase alcalina e a síntese de matriz condrogênica PAS+, safranina $O+$, alcian blue + e expressão de Sox-9 e colágeno-II. Conclui-se que a cafeína, nas concentrações de 0,5, 1,0, 2,0mM, apresenta efeito inibidor direto sobre a condrogênese em culturas de condrócitos de ratos.

Palavras-chave: ratos, cafeína, condrócitos, condrogênese

Recebido em 30 de março de 2017

Aceito em 3 de janeiro de 2018

*Autor para correspondência (corresponding author)

E-mail: serakidesufmg@gmail.com 


\section{INTRODUCTION}

During the fetal period, most bones are derived from endochondral bone formation, in which mesenchymal stem cells (MSCs) differentiate into chondroblasts, forming a cartilage mold that is gradually replaced with bone (Adams et al., 2007). During the postnatal period, the chondroblasts of the epiphyseal plate and articular cartilage, remnants of the cartilaginous mold, proliferate and differentiate to induce endochondral bone growth, which determines the final lengths of adult bone (Mackie et al., 2008).

During proliferation, chondroblasts secrete a matrix rich in collagen type II and aggrecan during the chondrocyte maturation phase, which is characterized by cellular hypertrophy and the expression of collagen type $\mathrm{X}$ and alkaline phosphatase (Garimella et al., 2004). These matrix constituents, in turn, are regulated by the transcription factors Sox-9 and Runx-2, which exert their effects during the early and late stages of the chondrogenic differentiation (Komori, 2003; Hino et al., 2014). Sox-9 acts as an inducer of mesenchymal condensation and the initiation of chondrogenic differentiation, whereas Runx-2 acts as a regulator for determining chondrocyte hypertrophy, vascular invasion and the subsequent replacement of cartilage by bone tissue (Komori, 2003; Hino et al., 2014).

Various bone pathologies may arise from any interference during the various stages of chondrogenesis and or due to the disturbance of its regulators (Yan et al., 2012). Caffeine is a substance that can alter bone growth (Reis et al., 2014). In addition, as caffeine is widely consumed by the human population, it can be conveyed by the placenta and via transmammary passage, interfering with the formation and endochondral bone growth of offspring (Reissig et al., 2009). There are several reports of the effects of caffeine on bone tissue and its cells (Tassinari et al., 1991; Tsuang et al, 2006; Reis et al., 2014), but there are no studies reporting its effect on chondrocytes, despite the knowledge that a mother's caffeine consumption during pregnancy and lactation affects the growth of the offspring's cartilage (Reis et al., 2014). Caffeine, which is transferred from mother to offspring, causes disorganization of areas of the epiphyseal plate and a glycosaminoglycan deficiency in cartilage matrix (Reis et al., 2014). Moreover, reductions in bone length and density have been observed (Reis et al., 2014). However, to elucidate the genesis of the changes caused by caffeine on the cartilage, further studies on the cellular and molecular mechanisms by which caffeine acts on chondrocytes are needed.

Regarding bone tissue cells, it is known that caffeine acts on osteoblasts (Tassinari et al., 1991; Tsuang et al., 2006) reducing cell viability (Tsuang et al., 2006) and inhibiting synthesis by activating cell death (Tassinari et al., 1991). Osteoblast cultures treated with high concentrations of caffeine showed lower expressions of genes, enzymes and proteins that are naturally expressed during osteogenesis, such as Runx-2, alkaline phosphatase, collagen type I, osteocalcin, osteopontin, histone and vitamin D receptor (Tassinari et al., 1991; Rapuri et al., 2007). In MSCs, high concentrations of caffeine suppresses cell differentiation, decreased mineralization and alkaline phosphatase activityregulating genes, such as osteocalcin, osteoprotegerin and Runx-2 (Su et al., 2013). The inhibitory effect of caffeine on the osteogenic differentiation of MSCs was also observed in a study that investigated the MSCs of the offspring of rats given caffeine during pregnancy and lactation (Reis et al., 2016).

The effect of caffeine in osteoblasts and MSCs may explain some of the mechanisms by which it causes osteopenia but does not provide information on the genesis of the growth changes caused by this alkaloid (Tassinari et al., 1991; Rapuri et al., 2007; Reis et al., 2016), as the effects of caffeine on chondrocyte viability and synthesis activity have not been studied.

Thus, using cultured chondrocytes extracted during the growth phase from rat cartilage as an experimental model, the aim of this study was to evaluate the effects of various concentrations of caffeine on cell viability and synthesis activity to elucidate the mechanisms by which caffeine reduces endochondral bone growth.

\section{MATERIALS AND METHODS}

All experimental procedures were approved by the Ethics Committee in Animal Experimentation of Universidade Federal de Minas Gerais (UFMG) (protocol no. 3/2013). 
The extraction of chondrocytes from cartilage was performed as reported previously (Chen et al., 2010).

Fifteen Wistar rats female at three days of age were euthanized by an overdose of anesthetic (2,5\% Tionembutal; Abbott, São Paulo, Brazil). There are reliable visible criteria for sex determination for the newborn rat. Both the size of the genital papilla and the ano-genital distance (AGD) show clear-cut differences between the sexes, with AGD providing the most objective criteria for sexing, considering the AGD in the female is higher compared to male (Farris, 1942).

The skin of the hind limbs and then the femurs and tibias of all animals were disinfected with $70 \%$ ethanol and povidone-iodine and were then dissected from the muscle tissues and surrounding connective tissue using sterile instruments in a laminar flow hood and washed in sterile $0.15 \mathrm{M}$ phosphate buffered saline (PBS) (Synth, São Paulo, SP, Brazil).

Cartilage sections were immediately harvested from the proximal and distal ends of the bones and incubated overnight with $0.4 \%$ collagenase (Sigma-Aldrich, St. Louis, MO, USA) in Dulbecco's modified Eagle's medium (DMEM) (Gibco, Grand Island, NY) supplemented with gentamycin $(60 \mu \mathrm{g} / \mathrm{L})$, penicillin $(100 \mathrm{U} / \mathrm{ml})$, streptomycin $(100 \mathrm{mg} / \mathrm{ml})$ and amphotericin $(25 \mathrm{mg} / \mathrm{L})$ (Merck, Germany) for isolation of chondrocytes (Chen et al., 2010).

Chondrocytes suspensions were centrifuged for 10 minutes at $1400 \mathrm{rpm}$ and washed with PBS (Synth, São Paulo, SP, Brazil). After further centrifugation, the cells were resuspended and cultured in T25 flasks (TPP, Techno Plastic Products in Trasadingen) containing chondrogenic medium (Chen et al., 2010).

This medium was composed of DMEM supplemented with ascorbic acid $(50 \mu \mathrm{g} / \mathrm{ml})$ (Sigma-Aldrich, St. Louis, MO, USA), 10-7M dexamethasone (Sigma-Aldrich, St. Louis, MO, USA), $6.25 \mu \mathrm{g} / \mathrm{ml}$ insulin (Biobras, Brazil), $6.25 \mu \mathrm{g} / \mathrm{ml}$ transferrin (Sigma-Aldrich, St. Louis, MO, USA), $1 \mathrm{mM}$ pyruvate (Sigma-Aldrich, St. Louis, MO, USA), $1.25 \mu \mathrm{g} / \mathrm{ml}$ BSA (SigmaAldrich, St. Louis, MO, USA) and with $1 \%$ fetal bovine serum (Gibco, Grand Island, NY, USA) (Chen et al., 2010).
The cultures were maintained in an incubator at $37^{\circ} \mathrm{C}$ with $5 \% \mathrm{CO} 2$, and the culture medium was changed every two days. After the cells reached 80-90\% confluence, the cultures were trypsinized and cultured in chondrogenic medium (control group) or chondrogenic medium supplemented with various concentrations of caffeine $(0.5 \mathrm{mM}$, $1.0 \mathrm{mM}$ and $2.0 \mathrm{mM}$ ) (Sigma-Aldrich, St. Louis, MO, USA) (Rapuri et al., 2007; Su et al., 2013).

The cultures were maintained on plates with 6 or 24 wells, depending on the type of assay to be performed. Four groups with six cultures/group were established to evaluate cell viability, alkaline phosphatase activity and collagen synthesis at 7, 14 and 21 days of cultivation. The percentage of chondrogenic cells and matrix and the expression of gene transcripts in the chondrogenic matrix, including aggrecan, collagen II, alkaline phosphatase, Runx-2 and Sox -9 , were evaluated at 21 days of cultivation.

At 7, 14 and 21 days of cultivation, chondrocytes were incubated with MTT (3- (4,5dimethylthiazol-2-yl) -2,5 diphenyltetrazolium bromide) (Invitrogen, Eugene, Oregon, USA) for 2 hours at $37^{\circ} \mathrm{C}$. After incubation, the cells were treated for 12 hours with a solubilization solution (sodium dodecyl sulfate in $10 \% \mathrm{HCl}$ ) (Synth,

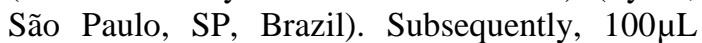
were transferred to 96 -well plates for reading on a spectrophotometer at an absorbance of $595 \mathrm{~nm}$ (Valerio et al., 2004). Six repetitions of the analysis were performed per group.

At 7, 14 and 21 days of cultivation, chondrocytes were incubated with BCIP/NBT (5-bromo-4chloro-3-indolylphosphate nitroblue tetrazolium) solution (Gibco, Grand Island, NY) for $2 \mathrm{~h}$ at $37^{\circ} \mathrm{C}$. After incubation, the cells were treated for 12 hours with solubilization solution (sodium dodecyl sulfate in $10 \% \mathrm{HCl}$ ) (Synth, São Paulo, SP, Brazil). Subsequently, $100 \mu 1$ were transferred to 96-well plates for reading on a spectrophotometer at an absorbance of $595 \mathrm{~nm}$ (Boeloni et al., 2009). Six repetitions of the analysis were performed per group.

At 7, 14 and 21 days of cultivation, the cell cultures were washed in PBS (Synth, São Paulo, SP, Brazil) and fixed in Bouin solution (Merk, Germany) for $2 \mathrm{~h}$ at $37^{\circ} \mathrm{C}$. After incubation, the cultures were washed with deionized water and air dried. The cells were stained with red sircol 
(Reagent, Rio de Janeiro, RJ, Brazil) for 30 minutes at room temperature, washed twice with $0.01 \mathrm{~N} \mathrm{HCl}$ solution (Synth, São Paulo, SP, Brazil), and treated with $0.5 \mathrm{M} \mathrm{NaOH}$ solution (Synth, São Paulo, SP, Brazil). Subsequently, $100 \mu \mathrm{L}$ were transferred to 96 -well plates for reading on a spectrophotometer at an absorbance of 540nm (Boeloni et al., 2009). Six repetitions of the analysis were performed per group.

After 21 days of culture, cells from all experimental groups, grown in six-well plates with sterile $22 \times 22 \mathrm{~mm}$ coverslips were washed with 0.15M PBS (Synth, São Paulo, SP, Brazil), fixed in 4\% paraformaldehyde (Synth, São Paulo, SP, Brazil) and subjected to staining with safranin $\mathrm{O}$, alcian blue and periodic acid-Schiff (PAS) (Sigma, St. Louis, MO, USA) (Prophet, 1992).

We analyzed the percentage of chondrocytes in the sections stained with Hematoxylin and eosin (HE) and the percentage of the chondrogenic matrix stained with safranin $\mathrm{O}$, alcian blue and PAS (Sigma, St. Louis, MO, USA). The analysis was performed using a 121-point graticule coupled to an optical microscope with a $10 \mathrm{X}$ objective in 50 microscopic fields (Reis et al., 2016). Six repetitions of the analysis were performed per group.

A quantitative evaluation of the gene transcript expressions of aggrecan, collagen II, Sox-9, Runx-2, and alkaline phosphatase were performed using RT-PCR for six cultures of each of the groups at 21 days of cultivation. Extraction of RNA from the cultured cells was performed using Trizol (Gibco, Grand Island, $\mathrm{NY}$ ) according to the manufacturer's instructions.

Briefly, $1 \mu \mathrm{g}$ of RNA was used for cDNA synthesis using a Superscript III Platinum TwoStep qPCR kit with SYBR Green (Invitrogen, Carlsbad, CA, USA). qRT-PCR was performed using a thermocycler Smart Cycler II (Cepheid, Carpinteria, CA, USA).

The first qRT-PCR amplification step was initiated with reverse transcription for 120 s at $50^{\circ} \mathrm{C}$ followed by PCR with the following parameters: 45 cycles of $15 \mathrm{~s}$ at $95^{\circ} \mathrm{C}$ and $30 \mathrm{~s}$ at $60^{\circ} \mathrm{C}$. At the end of each test, the fluorescence data were analyzed to obtain the CT values. Gene expressions were calculated using the $2^{\Delta \Delta \mathrm{Ct}}$ method, where the values of the samples were calculated relative to GAPDH $\mathrm{Ct}$ values. The Genes and nucleotide sequences of the primers used for RT-PCR were as follows: sense 5'-CAACTCCCTCA AGATTGTCAGCAA-3', antisense 5'-GGCATGGACTGTGGTCATGA-3' for GPDH (Acess number: NM_002046); sense 5'CACACGCTACACACTGGACT-3', antisense 5'TCACACTGGTGGAAGC CATC-3' for aggrecan (Acess number: NM_022190.1); sense 5'GTTCACGTACACTGCCCTGA-3', antisense 5' AAGGCGTGAGGTCTTC TGTG-3' for collagen II (Acess number: NM_012929.1); sense 5'CTAGTTCCTGGG AGATGGTA-3', antisense 5'GTGTTGTACGTCTTGGAGAGA-3' for alkaline phosphatase (Acess number: AC_000073.1); sense 5'-GCGTCAACACCATCATTCT-3', antisense 5'- CAGACCAGCAGCACTC CATC-3' for Runx-2 (Acess number: NM_ 004348); sense 5'CCCGATCTGAAGAAGGAGA GC-3', antisense 5'-G TTCTTCA CCGACTTCCTCCG-3' for Sox-9 (Acess number: NW_0473432).

Delineation was performed in a random manner, and the means and standard deviations were determined for each variable. We performed an ANOVA and compared the means using a Student-Newman-Keuls test (SNK) (Instat, version 3.00, 32 Win 95/NT; GraphPad Software, San Diego, CA, USA). The changes in the expressions of the gene transcripts measured via real-time PCR were compared using a SNK test after a logarithmic transformation of the data. Differences were considered significant for $\mathrm{P}<0.05$ (Sampaio, 1998).

\section{RESULTS}

At 7 days, only cultures of chondrocytes treated with caffeine at a concentration of $0.5 \mathrm{mM}$ exhibited MTT conversion in the formazan crystals significantly lower compared to the control and significantly lower compared to the other groups treated with caffeine. However, at 14 and 21 days of culture, all groups treated with caffeine at concentrations of $0.5,1.0$ and $2.0 \mathrm{mM}$ showed less cell viability, which was characterized by a significant reduction in the conversion of MTT in the formazan crystals. At 14 days, all groups treated with caffeine showed significant differences when compared to one another (Figure 1). 


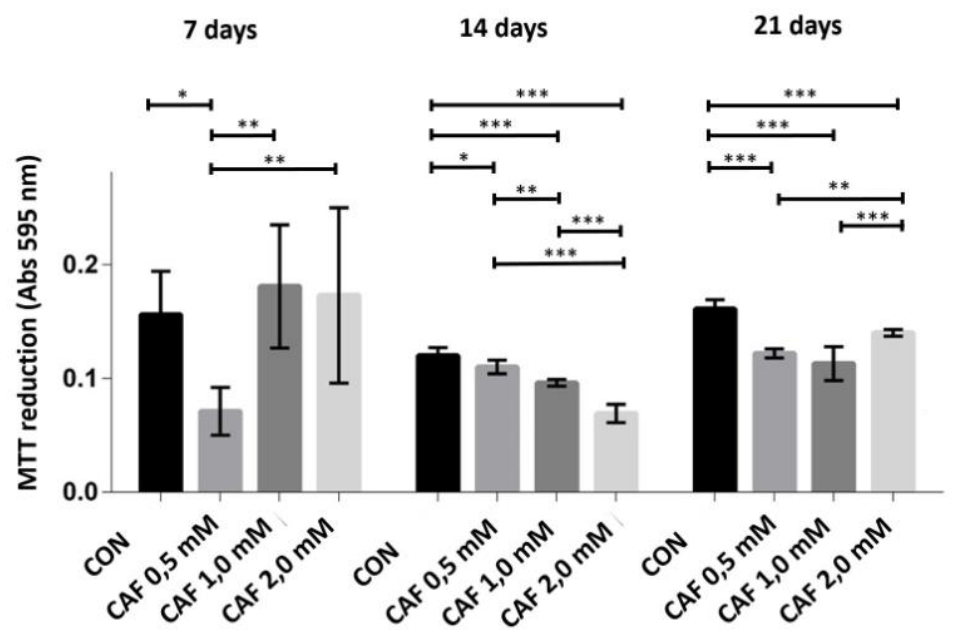

Figure 1. The conversion of MTT into formazan crystals (mean \pm standard deviation) in sextuplicate for each experimental group in chondrocyte cultures derived from neonatal rat articular cartilage without caffeine (control) and with various concentrations of caffeine $(0.5,1.0$ and $2.0 \mathrm{mM})$ at 7,14 and 21 days of cultivation. $* \mathrm{P}<0.05, * * \mathrm{P}<0.01, * * * \mathrm{P}<0.001$ (SNK test).

At 7 days, all groups treated with caffeine at concentrations of $0.5,1.0$ and $2.0 \mathrm{mM}$ showed significantly higher alkaline phosphatase activity compared to the control. However, the groups treated with caffeine at concentrations of 1.0 and $2.0 \mathrm{mM}$ showed a significant reduction compared to the group treated with caffeine at a concentration of $0.5 \mathrm{mM}$. At 14 and 21 days, all groups treated with caffeine showed significantly lower alkaline phosphatase activity compared to the control, and each group differed significantly when compared to one another (Figure 2).

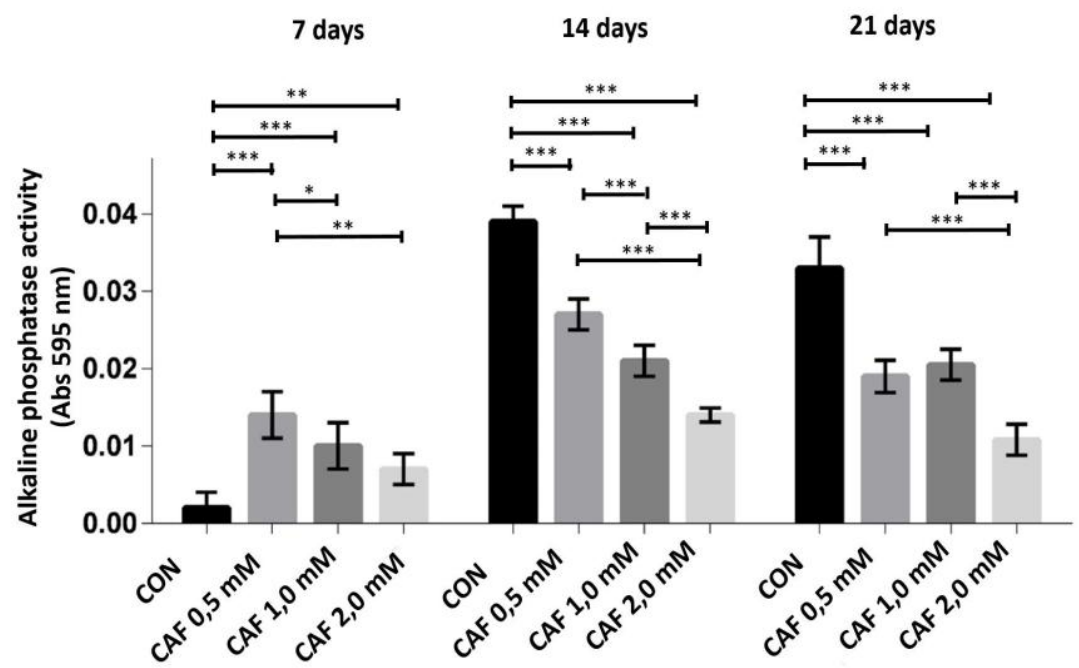

Figure 2. Alkaline phosphatase activity (mean \pm standard deviation) in sextuplicate for each experimental group into chondrocyte cultures derived from neonatal rat articular cartilage without caffeine (control) and with various concentrations of caffeine $(0.5,1.0$ and $2.0 \mathrm{mM})$ at 7,14 and 21 days of culture. $* \mathrm{P}<$ $0.05, * * \mathrm{P}<0.01, * * * \mathrm{P}<0.001$ (SNK test). 
At 7, 14 and 21 days, all groups treated with caffeine at concentrations of $0.5,1.0$ and $2.0 \mathrm{mM}$ exhibited significantly lower collagen synthesis compared to the control. At 7 days, the groups treated with caffeine at concentrations of 1.0 and $2.0 \mathrm{mM}$ showed a significantly lower collagen synthesis compared to the group treated with $0.5 \mathrm{mM}$ caffeine. At 14 and 21 days, all of the groups treated with caffeine exhibited significant differences when compared to one another (Figure 3).

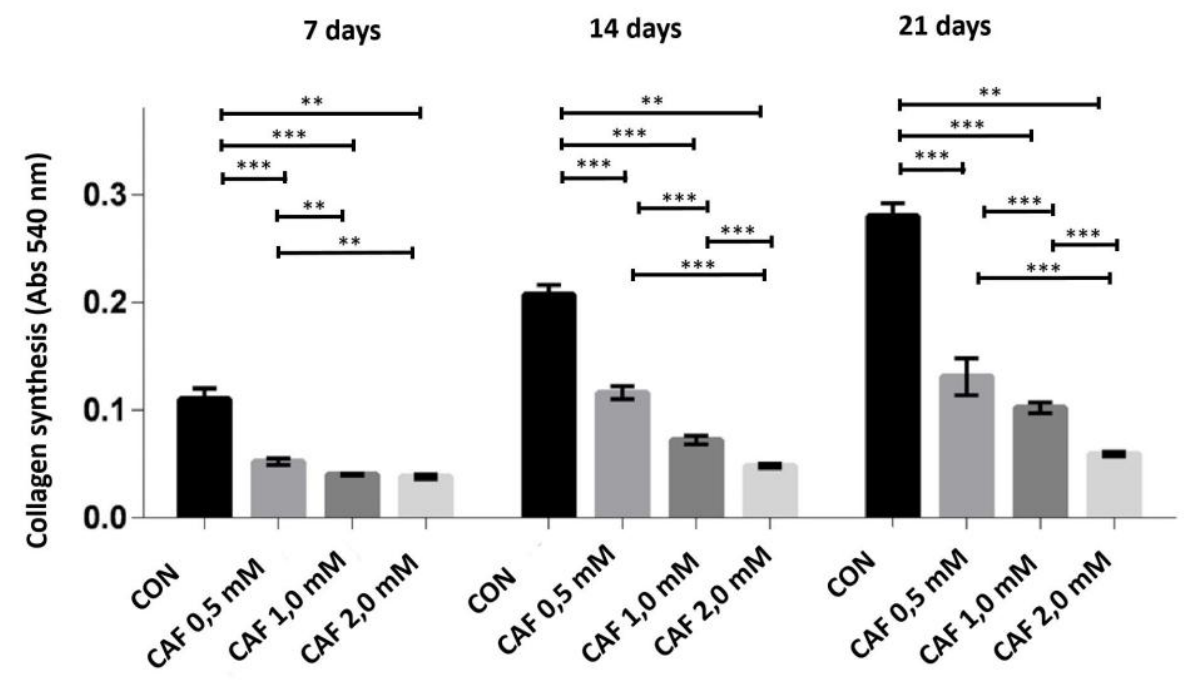

Figure 3. Collagen synthesis (mean \pm standard deviation) in sextuplicate for each experimental group in chondrocyte cultures derived from neonatal rat articular cartilage without caffeine (control) and with various concentrations of caffeine $(0.5,1.0$ and $2.0 \mathrm{mM})$ at 7,14 and 21 days of culture. $* * \mathrm{P}<0.01$, ***P< 0.001 (SNK test).

At 21 days, all groups treated with caffeine at concentrations of $0.5,1.0$ and $2.0 \mathrm{mM}$ showed a significant reduction in the percentage of chondrocytes/microscopic field compared to the control, and the groups showed significant differences when compared to one another (Figure 4).

At 21 days, all groups treated with caffeine at concentrations of $0.5,1.0$ and $2.0 \mathrm{mM}$ showed a significant and intense reduction in the percentage of chondrogenic matrix per microscopic field that were positive for PAS (Figure 5), alcian blue (Figure 6) and safranin O (Figure 7) compared to the control.
At 21 days, all groups treated with caffeine showed a significant and intense reduction in the quantification of gene transcripts for aggrecan, collagen II, and Sox-9 compared to the control. However, the groups treated at various concentrations of caffeine showed no significant difference when compared to one another (Figure 8A, B and C).

All the caffeine-treated groups showed no significant difference in the quantification of gene transcripts for Runx-2 and alkaline phosphatase compared to the control and to one another (Figure 8D and E). 

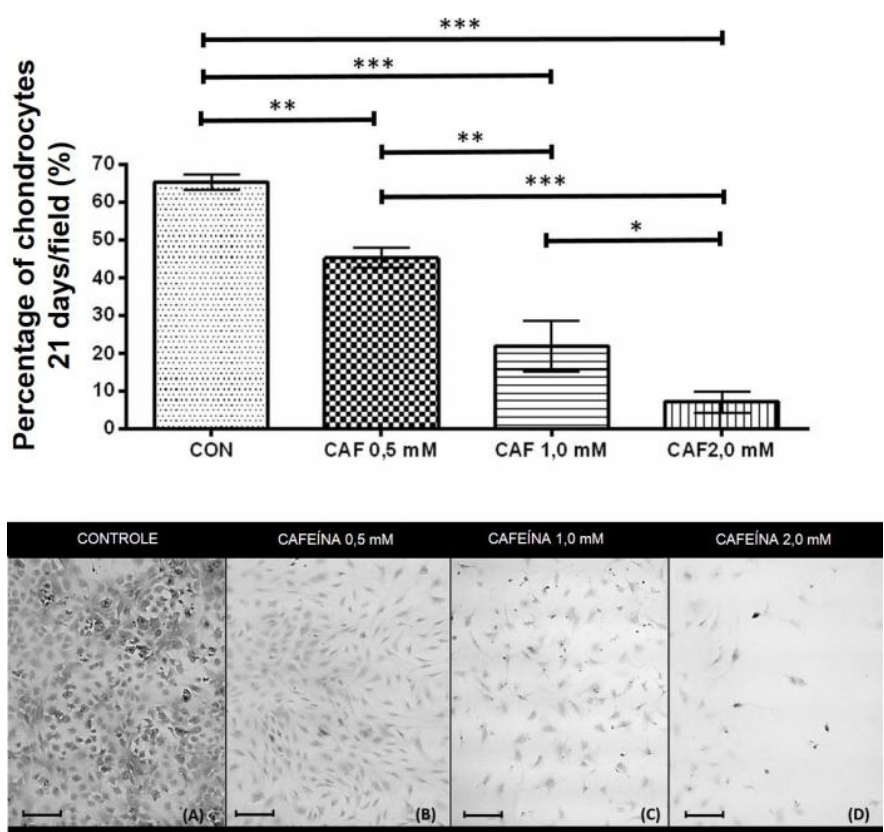

Figure 4. Percentage of chondrocytes/microscopic field (mean \pm standard deviation) in sextuplicate for each experimental group in chondrocytes cultures extracted from the articular cartilage of newborn rats grown without caffeine (control) and with various concentrations of caffeine $(0.5,1.0$ and $2.0 \mathrm{mM})$ at 21 days of cultivation. Bar: $58.5 \mu \mathrm{m}$. $* \mathrm{P}<0.05$, $* * \mathrm{P}<0.01, * * * \mathrm{P}<0.001$ (SNK test).

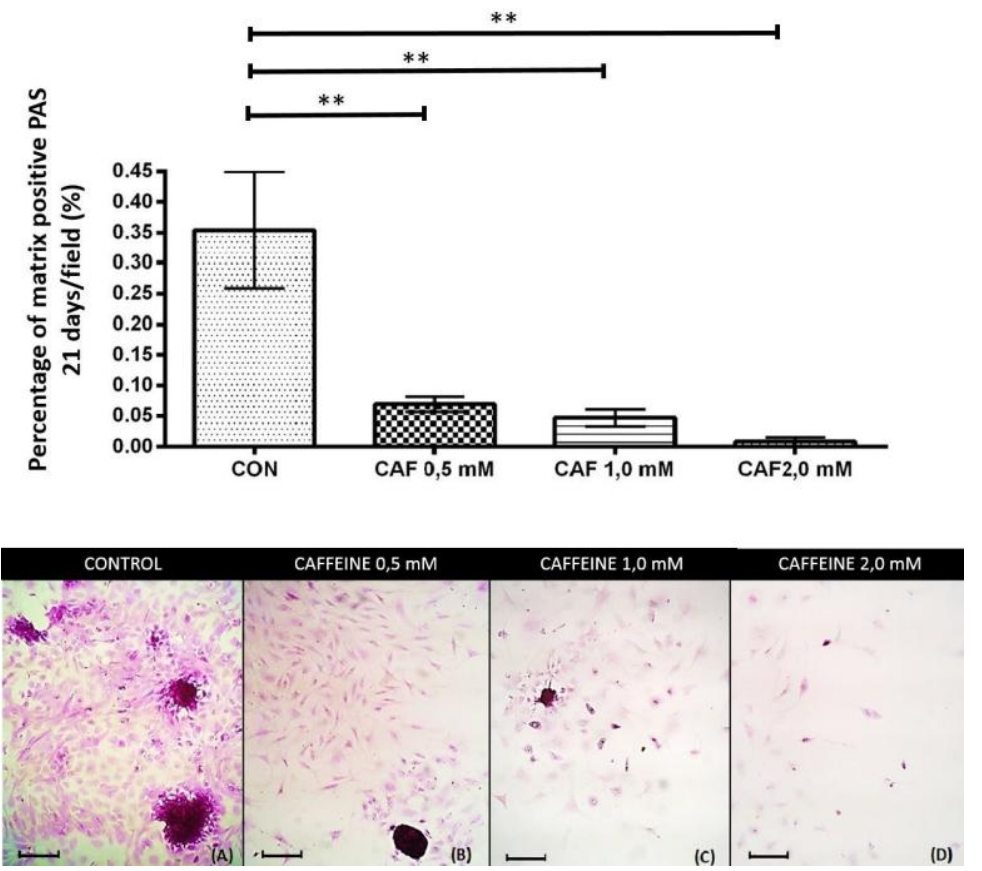

Figure 5. Percentage of the chondrogenic matrix/PAS positive microscopic field (mean \pm standard deviation) in sextuplicate for each experimental group in the chondrocyte cultures extracted from the articular cartilage of newborn rats grown without caffeine (control) and with various concentrations of caffeine $(0.5,1.0$ and $2.0 \mathrm{mM})$ at 21 days of culture. Bar: $58.5 \mu \mathrm{m} .{ }^{*} \mathrm{P}<0.01$ (SNK test). 


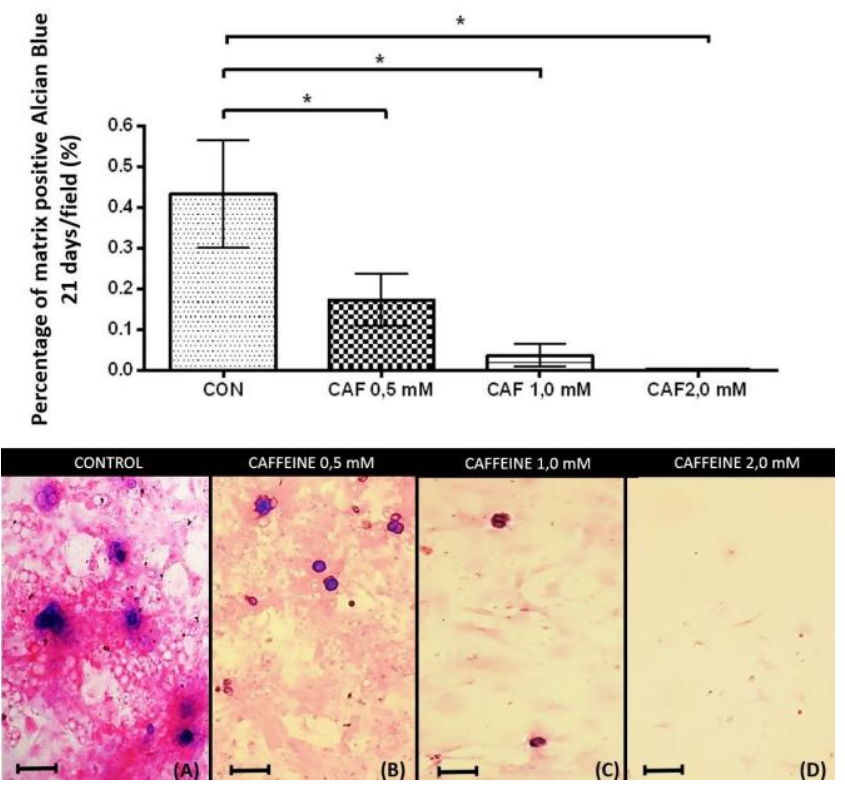

Figure 6. Percentage of the chondrogenic matrix/alcian blue positive microscopic field (mean \pm standard deviation) in sextuplicate for each experimental group in the chondrocyte cultures derived from neonatal rat articular cartilage in various concentrations of caffeine in vitro $(0,0.5,1.0$ and $2.0 \mathrm{mM})$ at 21 days of culture. Bar: $58.5 \mu \mathrm{m} . * \mathrm{P}<0.05$ (SNK test).
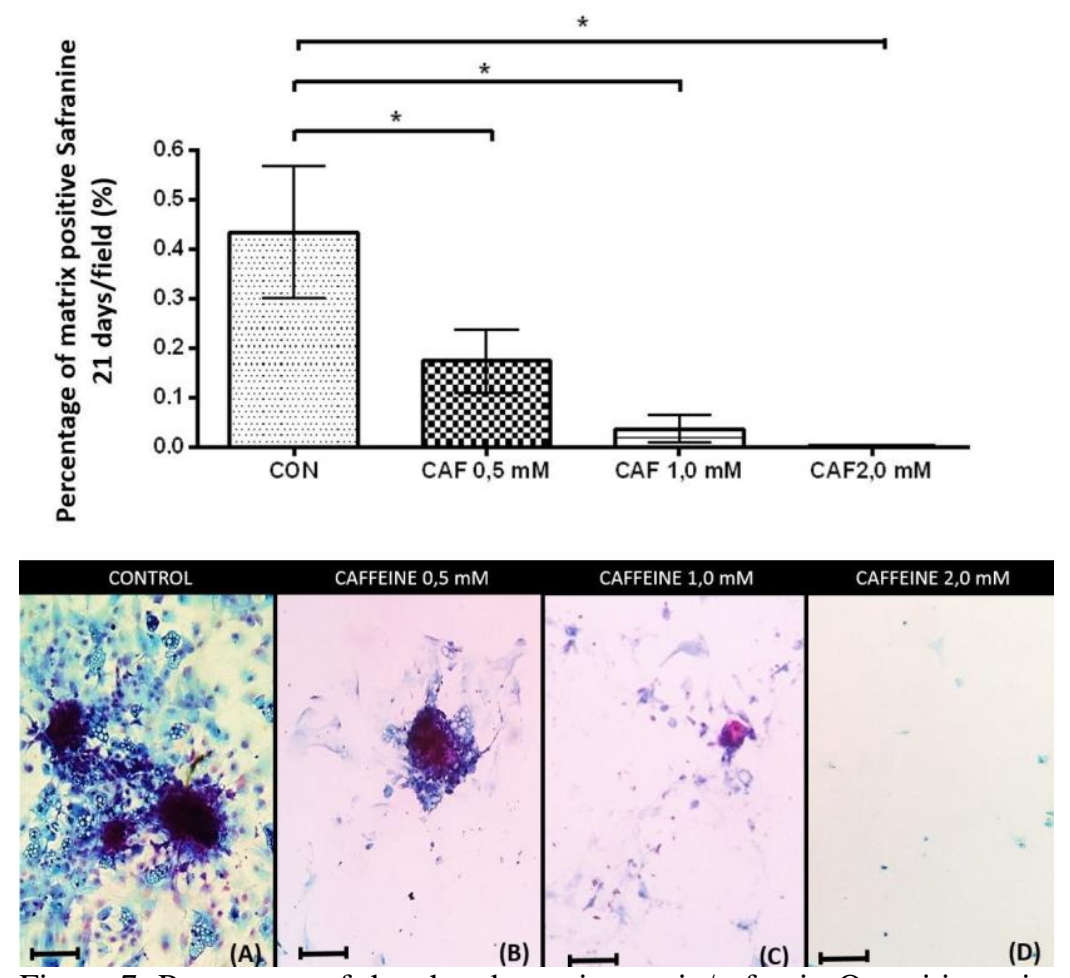

Figure 7. Percentage of the chondrogenic matrix/safranin $\mathrm{O}$ positive microscopic field (mean \pm standard deviation) in sextuplicate for each experimental group in the chondrocyte cultures extracted from the articular cartilage of newborn rats grown without caffeine (control) and with various concentrations of caffeine $(0.5,1.0$ and $2.0 \mathrm{mM})$ at 21 days of culture. Bar: $58.5 \mu \mathrm{m} . * \mathrm{P}<0.05$ (SNK test). 
曰

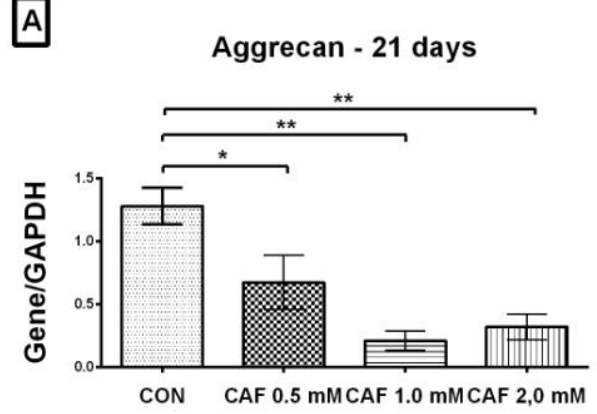

๑

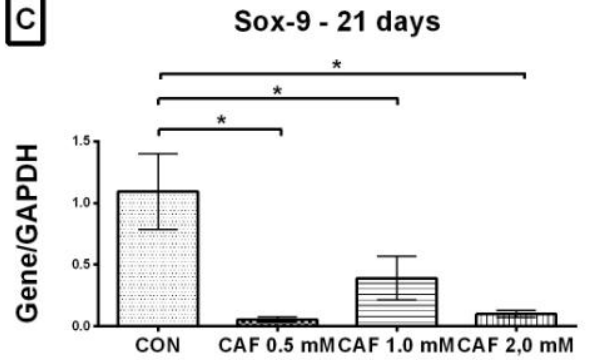

B

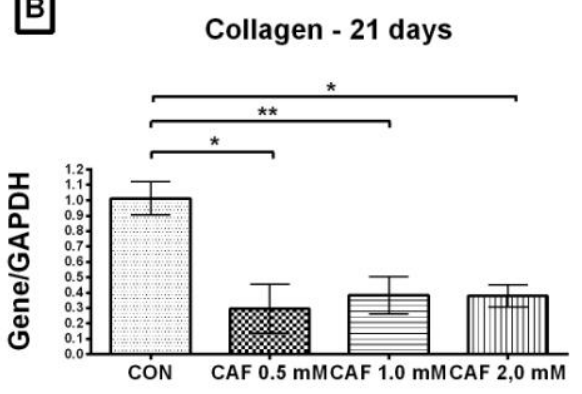

D

Runx-2 - 21 days

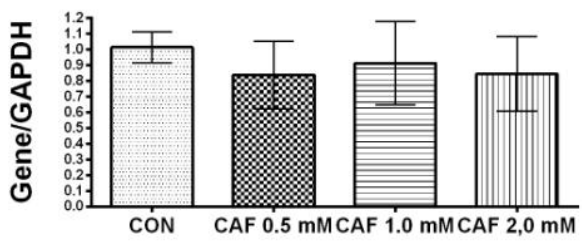

E Alkaline phosphatase - 21 days

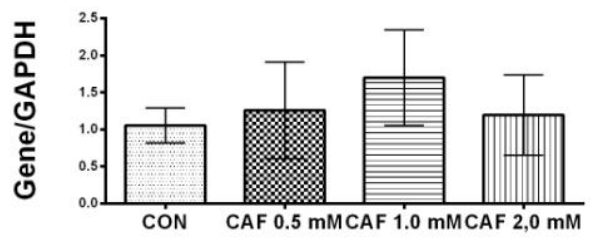

Figure 8. Comparison of relative quantification (mean \pm standard deviation) in quadruplicate for each experimental group of gene transcripts for aggrecan (A), collagen II (B), Sox-9 (C), Runx-2 (D), and alkaline phosphatase (E) by RT-PCR in chondrocyte cultures derived from the articular cartilage of neonatal rats cultured without caffeine (control) and with various concentrations of caffeine $(0.5,1.0$ and $2.0 \mathrm{mM})$ at 21 days of cultivation. $* \mathrm{P}<0.05, * * \mathrm{P}<0.01$ (SNK test).

\section{DISCUSSION}

This is the first study to demonstrate the negative effect of caffeine on chondrogenesis using cultures of chondrocytes extracted from cartilage as an experimental model. For all of the studied concentrations, caffeine significantly decreased cell viability, which was characterized by a reduction in the conversion of MTT to formazan, the percentage of chondrocytes/microscopic field and the synthesis activity of the chondrocytes, represented by a significant reduction in alkaline phosphatase activity, collagen synthesis, matrix synthesis and the expression of gene transcripts for aggrecan, collagen II and Sox-9.
In the MTT conversion assay (formazan crystals), only the cultures treated with $0.5 \mathrm{mM}$ caffeine had a lower cell viability at seven days compared to the control. However, at 14 and 21 days of cultivation, the chondrocytes of all of the groups treated with caffeine showed less cell viability compared to the control. For all periods studied, there were also significant differences in cell viability for comparisons among the groups treated with caffeine. Thus, decreased cell viability was observed in the group treated with the higher concentration of caffeine and vice versa, demonstrating that the effect of caffeine on MTT reduction is concentration-dependent. 
The MTT assay is a quantitative colorimetric method that assesses cell viability based on mitochondrial enzyme activity, as the formation of formazan crystals depends on the activity of succinate dehydrogenase, which is found in the mitochondria of viable cells (Holt et al., 1987). It is likely that the reduction in MTT to formazan observed in chondrocytes treated with caffeine may be due to the effect of caffeine on mitochondria, as in osteoblast cultures, caffeine reduces mitochondrial integrity, altering their membrane potential and permeability (Rapuri et al., 2007). In these cultures, caffeine at concentrations of $10-20 \mu \mathrm{M}$ also reduced cell viability by stimulating intracellular oxidative stress, causing cell death by modulating Bax/Bcl2 , which are the primary effectors of the apoptotic pathway (Rapuri et al., 2007; Su et al., 2013).

All concentrations of caffeine changed the alkaline phosphatase activity, increasing it in the first seven days and then significantly reducing alkaline phosphatase activity at 14 and 21 days compared to control. The oscillation of this parameter can occur primarily in the early stages of culture (Hoemann et al., 2009). Similarly, dexamethasone $(10 \mathrm{nM}$ or $100 \mathrm{nM})$ stimulates alkaline phosphatase activity during the first week of MSC cultures (Cheng et al., 1994), then promoting the activity of the enzyme after three weeks of suppression (Yin et al., 2006). It is known that caffeine acts in synergy with dexamethasone and activates receptors for glucocorticoids in bone cell cultures (Focking et al., 2005). Thus, one hypothesis is that dexamethasone added to the chondrogenic medium may influence the effect of caffeine on alkaline phosphatase activity in chondrocytes. However, this is a hypothesis that requires further investigation.

During all periods, there were significant differences among all of the treated groups in alkaline phosphatase activity. Thus, the lower activity of alkaline phosphatase was observed in the group treated with the higher concentration of caffeine and vice versa, demonstrating that, similar to the MTT assay, the effect of caffeine on alkaline phosphatase activity is concentration dependent. Alkaline phosphatase is a marker of mature chondrocytes, and therefore, a decrease in the later stage of cultivation suggests a delay in chondrogenic maturation. This may be one reason that caffeine reduces the synthesis of the chondrogenic matrix, which is an important indicator of maturation and differentiation (Garimella et al., 2004).

Despite the reduction in alkaline phosphatase activity in the groups treated with caffeine at 21 days of culture according to the colorimetric test, there was no significant difference in gene transcript expression of alkaline phosphatase during the same period. This divergence of results may be explained by the fact that colorimetric tests assess enzymatic synthesis, whereas the RT-PCR evaluates gene expression. Furthermore, in colorimetric testing, the results can vary depending on the number of cultured cells; there is always a need to supplement colorimetric tests with more accurate tests, such as RT-PCR. In the present study, it is likely that the decreased alkaline phosphatase activity was due to reduced cell viability and cell percentages rather than a reduction in phosphatase levels synthesized by chondrocytes, as RT-PCR revealed no difference between the treated and control groups regarding the expression of the alkaline phosphatase transcript.

Unlike alkaline phosphatase, reduced collagen synthesis according to the colorimetric assay demonstrated that all groups treated with caffeine were associated with a reduced expression of the transcribed gene for collagen II, as determined via RT-PCR. Thus, it is likely that the reduction in the percentage of cells was not the only reason there was a reduction in collagen synthesis. Chondrocytes under the effect of caffeine may present a reduced ability to synthesize collagen. Collagen is a major constituent of the extracellular matrix (Garimella et al., 2004), and therefore, its reduction may be one reason explaining why there was less matrix synthesis in the groups treated with caffeine. In addition, the synthesized matrix in the chondrocytes of the groups treated with caffeine showed a reduced expression of aggrecan according to RT-PCR, less glycogen and glycoproteins according to PAS staining, less hyaluronic acid and sulfated mucosubstances according to alcian blue staining, and less total proteoglycan and glycosaminoglycans according to safranin $\mathrm{O}$ staining. These results suggest that caffeine reduces the synthesis of the chondrogenic matrix, not only the reducing cellularity, but also by 
reducing the expression of matrix gene transcripts, such as collagen II and aggrecan.

The extracellular matrix, which depends on proteoglycans, glycosaminoglycans, aggrecan and collagen, plays an important role in controlling growth and cell differentiation (Souza and Pinhal, 2011). In the cell, the protein structure of proteoglycans is synthesized on ribosomes and transferred to the endoplasmic reticulum. Binding to glycosaminoglycan chains is conducted in the Golgi complex, which include steps involved in the activity of several enzymes (Souza and Pinhal 2011). After the release of glycosaminoglycans in the matrix, desulfation and degradation must occur (Mertz et al., 2012). Because a deficiency in glycosaminoglycans and proteoglycans in the matrix reduces differentiation and cell growth, it is likely that impairment of glycosaminoglycans and proteoglycans in chondrocytes cultures treated with caffeine is one of the reasons why there was a reduction in cell viability and cellularity in all of the treated groups.

At 21 days, a reduction in the gene transcript for Sox-9 was observed in all of the groups treated with caffeine. However, there was no difference among groups with respect to the gene transcript expression for Runx-2. Sox-9 expression is essential in several successive stages of differentiation of chondroprogenitor cells via activation or transcriptional repression (Leung et al., 2011). Sox-9 is a primary regulator of chondrogenic differentiation (Akiyama et al., 2002), acting in the early stages of proliferation and differentiation of chondrocytes (Komori et al., 2003; Hino et al., 2014). Thus, it is likely that caffeine exerts its effect on reducing cellularity and matrix synthesis via interference with Sox-9.

Previous experiments have shown that Runx-2 is expressed at high levels during early chondrogenesis (Komori et al., 2003). However, after birth, Runx-2 becomes less expressed by pre-hypertrophic and hypertrophic chondrocytes (Inada et al., 1999). Studies have shown that Runx-2 alone is not sufficient to induce the differentiation of chondrocytes, which requires joint action with other factors, including, IHH, BMPs, VEGFs and collagen type X (Takeda et al., 2001). In fact, caffeine changes all of the parameters studied, even though there were no differences among groups with respect to Runx-2 expression.

In conclusion, caffeine added to rat chondrocytes cultures reduced cell viability, cellularity, matrix synthesis activity, and the expression of aggrecan, Sox-9 and collagen II gene transcripts. A concentration-dependent effect was only observed in tests for cell viability, cellularity, collagen synthesis and alkaline phosphatase activity.

These changes may be linked to the reduction in endochondral bone growth that results from caffeine consumption. The authors declared no potential conflicts of interest with respect to the research, authorship, and/or publication of this article.

This work was supported by grants from Fundação de Amparo à Pesquisa de Minas Gerais (Fapemig), Conselho Nacional de Desenvolvimento Científico e Tecnológico $(\mathrm{CNPq})$ and Pró-Reitoria de Pesquisa (PRPq) of the Universidade Federal de Minas Gerais.

\section{REFERENCES}

ADAMS, S.L.; COHEN, A.J.; LASSOVA, L. Integration of signaling pathways regulating chondrocyte differentiation during endochondral bone formation. J. Cell Physiol., v.213, p.635-641, 2007.

AKIYAMA, H.; CHABOISSIER, M.C.; MARTIN, J.F. et al. The transcription factor Sox 9 has essential roles in successive steps of the chondrocyte differentiation pathway and is required for expression of Sox5 and Sox6. Genes Dev., v.16, p.2813-28, 2002.

BOELONI, J.N.; OCARINO, N.M.; MELO, A.B. et al. Dose dependent effects of Triiodothyronine on the osteogenic differentiation of rat bone marrow mesenchymal stem cells. Horm. Res., v.72, p.88-97, 2009.

CHEN, K.S.; TATARCZUCH, Y.A.; HUANG, H.H. et al. Identification of light and dark hyphertrophic chontocytes in mouse and rat chondrocyte pellet cultures. Tissue Cell., v.44, p.124-128, 2010.

CHENG, S.L.; YANG, J.W.; RIFAS, L. et al. Differentiation of human bone-marrow osteogenic stromal cells in vitro - induction of the osteoblast phenotype by dexamethasone. Endocrinology, v.134, p.277-286, 1994.

FARRIS, E.J. The breeding of the rat: the rat in laboratory investigation. 2.ed. Philadelphia: Lippincott, 1942. 
FÖCKING, M.; SCHMIEGELT, D.; TRAPP, T. Caffeine-mediated enhancement of glucocorticoid receptor activity in human osteoblastic cells. Biochem. Biophys. Res. Commun., v.1337, p.435-439, 2005.

GARIMELLA, R.; BI, X.; CAMACHO, N. et al. Primary culture of rat growth plate chondrocytes: in vitro model of gowth plate histotype, matrix vesicle biogenesis and mineralization. Bone, v.34, p.961-970, 2004.

HINO, K.; SAITO, A.; KIDO, M. et al. Master regulator for chondrogenesis, Sox9, regulates transcriptional activation of the endoplasmic reticulum stress transducer BBF2H7/CREB3L2 in chondrocytes. J. Biol. Chem., v.289, p.13810-13820, 2014.

HOEMANN, C.D.; EL-GABALAWY, H.; MCKEE, M.D. In vitro osteogenesis assays: influence of the primary cell source on alkaline phosphatase activity and mineralization. Pathol. Biol., v.57, p.318-323, 2009.

HOLT, P.S.; BUCKLEY, S.; DELOACH, J.R. Detection of the lethal effects of T-2 mycotoxin on cells using a rapid colorimetric viability assay. Toxicol. Lett., v.39, p.301-312, 1987.

INADA, M.; YASUI, T.; NOMURA, S. et al. Maturational disturbance of chondrocytes in Cbfa1deficient mice. Dev. Dyn., v.214, p.279-290, 1999.

KOMORI, T. Requisite roles of Runx 2 and Cbfb in skeletal development. J. Bone Miner. Metab., v.21, p.193-197, 2003.

LEUNG, V.Y.; GAO, B.; LEUNG, K.K. et al. SOX9 governs differentiation stage-specific gene expression in growth plate chondrocytes via direct concomitant transactivation and repression. PLoS Genet., v.7, p.e1002356, 2011.

MACKIE, E.J.; AHMED, Y.A.; TATARCZUCH, L. et al. Endochondral ossification: How cartilage is converted into bone in the developing skeleton. Int. J. Biochem. Cell Biol., v.40, p.46-62, 2008.

MERTZ, E.L.; FACCHINI, M.; PHAM, A.T. et al. Matrix disruptions, growth, and degradation of cartilage with impaired sulfation. J. Biol. Chem., v.287, p.22030-22042, 2012.

PROPHET, E.B. Tissue processing: dehydratation, claring and infiltration. In: PROPHET, E.B, MILLS, B.; ARRINGTON, J.B.; SOBIN, L.H. AFIP Laboratory methods in histotechnology. Washington: Am. Registry of Pathology, 1992. 29p.

RAPURI, P.B.; GALLAGHER, J.C.; NAWAZ, Z. Caffeine decreases vitamin $D$ receptor protein expression and 1,25(OH)2D3 stimulated alkaline phosphatase activity in human osteoblast cells. $J$. Steroid Biochem. Mol. Biol., v.103, p.368-371, 2007.
REIS, A.M.S.; BATISTA, A.C.M.; OCARINO, N.M. et al. Effects of caffeine intake in mothers on maternal cortisol levels and offspring endochondral ossification. Actual. Osteol., v.10, p.20-36, 2014.

REIS, A.M.S.; BOELONI, J.N.; GOMES, D.A. et al. Inhibition of the osteogenic differentiation of mesenchymal stem cells derived from the offspring of rats treated with caffeine during pregnancy and lactation. Connect. Tissue Res., v.57, p.131-142, 2016.

REISSIG, C.J.; STRAIN, E.G.; GRIFFITHS, R.R. Caffeinated energy drinks: a growing problem. Drug Alcohol Depend., v.99, p.1-10, 2009.

SAMPAIO, I.B.M. Estatística aplicada à experimentação animal. Belo Horizonte: FEP/MVZ, 1998. 264p.

SOUZA, R.S.; PINHAL, M.A.S. Interações em processos fisiológicos: a importância da dinâmica entre matriz extracelular e proteoglicanos. Arq. Bras. Ciên. Saúde, v.36, p.48-54, 2011.

SU, S.J.; CHANG, K.L.; SU, S.H. et al. Caffeine regulates osteogenic differentiation and mineralization of primary adipose-derived stem cells and a bone marrow stromal cell line. Int. J. Food Sci. Nutr., v.64, p.429-36, 2013.

TAKEDA, S.; BONNAMY, J.; OWEN, M.J. et al. Continuous expression of Cbfa1 in nonhypertrophic chondrocytes uncovers its ability to induce hypertrophic chondrocyte differentiation and partially rescues Cbfa1-deficient mice. Genes Dev., v.15, p.467-481, 2001.

TASSINARI, M.S.; GERSTENFELD, L.C.; STEIN, G.S. et al. Effect of caffeine on parameters of osteoblast growth and differentiation of a mineralized extracellular matrix in vitro. Bone Miner. Res., v.6, p.1029-1036, 1991.

TSUANG, Y.H.; SUN, J.S.; CHEN, L.T. et al. Direct effects of caffeine on osteoblastic cells metabolism: the possible causal effect of caffeine on the formation of osteoporosis. J. Orth. Surg, Res., v.1, p.1-10, 2006.

VALERIO, P.; PEREIRA, M.M.; GOES, A.M. et al. The effect of ionic products from bioactive glass dissolution on osteoblast proliferation and colla-gen production. Biomaterials, v.25, p.2941-2948, 2004.

YAN, Q.; FENG, Q.; BEIER, F. Reduce chondrocyte proliferation, earlier cell cycle exit and increased apoptosis in neuronal nitric oxide synthase-deficient mice. Osteoarthr. Cartil., v.2, p.144-151, 2012.

YIN, L.; LI, Y.B.; WANG, Y.S. Dexamethasoneinduced adipogenesis in primary marrow stromal cell cultures: mechanism of steroid-induced osteonecrosis. Chin. Med. J., v.119, p.581-588, 2006. 